\title{
THE EFFECT OF SOCIAL CAPITAL AND KNOWLEDGE SHARING ON INNOVATION CAPABILITY
}

\author{
Dhyah Harjanti $^{1^{*}}$, Noerchoidah ${ }^{2}$ \\ ${ }^{1}$ Petra Christian University, Surabaya, Indonesia \\ ${ }^{2}$ Surabaya Merdeka University, Surabaya, Indoensia \\ *Corresponding author; Email: dhyah@petra.ac.id
}

\begin{abstract}
This research examines social capital and knowledge sharing effect on innovation capability among lectures in universities. Social capital was analyzed using three constructs, namely trust, norm and network, while knowledge sharing was broken down into two variables, namely knowledge collecting and knowledge donating. Innovation capability was explained on an individual level based on personality, behavioral and output perspectives. The research model and hypotheses were developed from the literature. Data collection is conducted through a survey on lecturers of private universities in Surabaya. The obtained data from the questionnaires were analyzed with the Partial Least Square (PLS) to investigate the research model. The results suggest that social capital significantly influences innovation capability, while high level of knowledge collecting and knowledge donating can lead to high level of innovation capability. This study offers a foundation to analyze the relationships between social capital, knowledge-sharing process, consisting of knowledge collecting and knowledge donating, and innovation capability.
\end{abstract}

Keywords: Social capital, knowledge sharing, innovation capability.

\section{Introduction}

In this knowledge economy era, a company could not only rely on mastery of technology, access into capital, and past success, to win the prevailing competitions. Now knowledge has become the basis of organizational competitive advantage, so that ideas concerning products and the application of the ideas on the products have become routine economy activities. The main asset of an organization is in the form of intellectual capital, which adheres to each individual and is intangible. With this intellectual capital, individuals could change information into knowledge (Nahapiet \& Ghoshal, 1998).

A considerable number of literatures show that social capital holds an significant part in economy, especially knowledge economy (Doh \& Zolnik, 2011), since social capital could facilitate and urge the forming of knowledge and exchange of research results, education, and research and development processes (Westlund, 2006; Doh \& Zolnik, 2011). Nahapiet and Ghoshal (1998) pointed out that social capital is involved in the creation of intellectual capital in an organization which could become the organization's advantages for meeting challenges.

This study will be a considerable endeavor in knowledge sharing stimulation in the workplace, particularly in universities. This study will also be beneficial to lecturers when they employ effective knowlegde sharing in order to, not only, collect external knowledge, but also to donate it. Initially, this will lead to the enhancement of the university's innovation capability.

\section{Social Capital}

Social capital is collective relationship that could deliver useful resources for an individual's interest in the present or in the future (Green, 1996). Unlike human capital, which is a combination of a person's attributes, skills or experiences, social capital consists of value and benefit, both actual and potential, which are produced by a person's social interactions (Santarelli \& Tran, 2012). Social capital could interact with human capital and financial capital. The benefits given by social capital also could be revealed as human resources and monetary assets (Doh \& Zolnik, 2011).

Social capital can be categorized into trust, connection set structure, and norms that encourage collaboration between actors to gain mutual benefits (Putnam, 1995). According to Putnam (2000), social capital is represented by recognized affiliation, public involvement, social reliance and altruism. Aside of being the main form of social capital, trust could also be gathered by collaborating within a public affiliation connection set (Fukuyama, 1995). The study by Onyx and Bullen (2000) discusses social capital as classified into trust, involvement within groups, mutuality, customs, social agents and community rules. Thus, 
social capital could be explained through three constructs which consist of reciprocal trust, affiliation, and community norms.

The preventive aspect of trust relates to the certainty that there is an efficient penalty mechanism in case of a breach of deals or contracts. This belief enables the establishment of cooperation and deals or contracts (Doh \& Zolnik, 2012). Previous researches show that trust and honesty could reduce transaction cost, create more efficient reciprocal relationship, and diminish frictions within social life (Fukuyama, 1995; Putnam, 2000). Therefore, trust is regarded as the main feature in communication and social exchange (Doh \& Zolnik, 2012).

Associational activities are the tendency of community members to be voluntarily involved in different sorts of organizations (Knack \& Keefer, 1997; Dakhli \& de Clercq, 2004; Doh \& Zolnik, 2012). This indicates the proximity with social set of connections and the level of openness of the networks. A study by Coleman (1990) shows that social network conclusiveness, cohesive ties encourage process the development of trust cooperation and interactions.

Community norm is people's tendency to cooperate and to put common interest above personal interest (Knack \& Keefer, 1997; Dakhli \& de Clercq, 2004). This mechanism occurs simultaneously with associational activities, since community members who are willing to develop their social condition tend to be more involved in various activities, and more inclined to share information, ideas, and knowledge (Dakhli \& de Clercq, 2004).

\section{Knowledge sharing}

Knowledge sharing is key element in the knowledge management practice used to create, harvest, and sustain business processes (Shah \& Mahmood, 2013; Alavi \& Leidner, 2001; Witherspoon, Jason, Cam, \& Dan, 2013), where organizational members collaborate to mutually facilitate, solve problems and develop new ideas (Pulakos, Dorsey, \& Borman, 2003). Successful knowledge sharing will enable an organization to enhance its innovative capabilities in response to a changing environment (Hansen, 1999; Collins \& Smith, 2006).

Knowledge sharing can be performed in various ways, determined by the kind of knowledge to be shared, i.e. tacit or explicit knowledge. Tacit knowledge is embedded in the subconscious level; therefore, it is usually more complicated to be shared (Faizuniah \& Aizzat, 2009). For that reason, tacit knowledge is commonly shared using face-to-face in- teractions, metaphors, images and other methods that do not require formal language use (Koskinen, Pihlanto, and Vanharanta, 2003; Fernie, Green, Weller, $\&$ Newcombe, 2003).

Meanwhile, explicit knowledge is more easily explained and shared, available in books, manuals, data bases, expert systems, training and various types of publications (Faizuniah \& Aizzat, 2009; Ipe, 2003; Koskinen et al., 2003). Explicit knowledge sharing activities will encourage every member of the organization to combine codified knowledge, to enable them to generate new knowledge and enhance innovation (Suresh, 2012).

Numerous previous researches show that knowledge sharing will enhance the ability and performance of corporate innovation (Lin, 2007; Yang \& Wu, 2008; Zhi-Hong, Li-Bo, \& Shu, 2008). Van den Hoff and de Ridder (2004) define a knowledge sharing process consists of either bringing (or donating) knowledge and gaining (or collecting knowledge). Knowledge donating is concerned with corresponding to others about one's intellectual abilities, whereas knowledge collecting is concerned with asking peers so that they can share their intellectual capital.

\section{Innovation Capability}

The innovation capability is an important organizational asset to survive and create competitive advantage (Terziovski, 2007; Bullinger, Bannert, \& Brunswicker, 2007). The innovation capability is the ability of corporations to routinely generate new and unique commercial values (Bullinger, Bannert, \& Brunswicker, 2007; Wallin, Larsson, Isaksson, \& Larsson, 2011; Terziovski, 2007). It includes the dimensions of product innovation, process innovation and management innovation (Lin, 2007; Plessis, 2007).

The capability of innovation is able to analyse both the individual and organizational levels. This research investigates innovation capability at individual level. The assessments of innovation capability at individual level are classified into: personality perspective, behavioral perspective and output perspective (Lin, 2007). The example of personality perspective or personality characteristics is the level of willingness to change from an individual. The behavioral perspective is indicated by the ability of individuals to try something new, while the perspective of output is shown by the ability of individuals to make something new (Lin, 2007). At the organization level, innovation capability can be measured by the ability to develop new products, to respond to technological changes, and to counter to competitors (Lin, 2007). 


\section{Hypotheses}

The correlation between social capital and knowledge sharing is widely discussed in prior studies (Tsai, 2005; Chow \& Chan, 2008; Sechi, Borri, Lucia, \& Celmins, 2011; Roussel \& Deltour, 2012). The relationship of social interaction, mutual trust, and team identification correlate to knowledge sharing intentions significantly (Akhavan \& Hosseini, 2016). According to van den Hooff and Huysman (2009), in the process of sharing knowledge, social capital acts by offering access to individuals with appropriate knowledge, shared interests, mutual trust, respecting the value of knowledge of others and having the capability to comprehend, interpret, and consider the other's knowledge. This research presumes social capital to influence lectures' inclination to share knowledge with colleagues in terms of both knowledge collecting and knowledge donating positively. The following two hypotheses are formulated:

$H_{l}$ : Social capital affects knowledge collecting positively.

$H_{2}$ : Social capital affects knowledge donating positively.

The ability of an organization's innovation is influenced by two basic processes of knowledge sharing, i.e. knowledge collecting and knowledge donating (Lin, 2007; Zhi-Hong et al., 2008; Yesil, Kosta, \& Buyukbese, 2013; Kamasak \& Bulutlar, 2010). Based on that previous study, the following hypotheses are suggested:

$H_{3}$ : Knowledge collecting affects knowledge donating positively.

$H_{4}$ : Knowledge collecting affects innovation capability positively.

$H_{5}$ : Knowledge donating affects innovation capability positively.

\section{Research Method}

\section{Population and Sample}

The unit analysis in this research is at the individual level. The empirical research bases on data obtained through questionnaires distributed among lecturers of private universities in Surabaya, East Java. The sample of this research is obtained by using a non-probability sampling technique. The questionnaires were distributed to 200 lectures of private universities in Surabaya. The total of returned ones was 134 and only 99 questionnaires were usable.

\section{Instrument and Measures}

The measurement items were taken from the literature and then adjusted to the research setting. All the items rates on a five-point Likert-type scale ranging from strongly disagree (1) to strongly agree (5). The data were analyzed by using Smart PLS 3 . Social capital items were operationalized as trust, network structure, and norms (Putnam, 2000). A sample item is as follows: "I believe the management is able to make good decisions for the future of university". Knowledge collecting items are derived from van den Hooff and de Ridder (2004). A sample item of knowledge collecting is as follows: "I asked my colleagues about their abilities when I wanted to learn something". Knowledge donating items are modified from van den Hooff and de Ridder (2004) as well. A sample item of knowledge donating is as follows: "When I have learned something new, I tell my colleagues about it".Item of innovation capability takes Lin's proxy (2007). A sample item is as follows: "I am improving my ability to produce new, more effective work procedures".

This research performs two-stage data analysis (Hair, Black, Babin, \& Anderson, 2010). First, it is done by evaluating the reliability and validity of the proxy. Second, partial least squares techniques are used to test the hypotheses (Chin, Marcolin, \& Newsted, 2003).

\section{Result and Discussion}

Table 1 depicts the results of first stage. The model has VIF values $<10$, hence there was no multicollinearity (Hair et al., 2010). As Table 1 presented, the individual item reliability of each standardized factor loading was significant and exceeded the recommended level 0.7. All construct composite reliability (CR) and Cronbach's $\alpha$ are above the benchmark 0.7 (Hair et al., 2010), consequently, the construct reliability is met. For convergent validity, all construct average variance extracted (AVE) is higher than the variance due to measurement error for that construct (that is AVE must > 0.50).

Table 2 shows the relationship among the constructs. The diagonal of the table presents the square root of the AVE. The entire square root of the AVE values are higher than the correlations between any pair of constructs, implying the satisfactory discriminant validity of the measure (Fornell \& Larcker, 1981).

As depicted in Table 3, all item loadings on the corresponding constructs are significant. The loadings on the cross-loading are smaller than loadings on the corresponding constructs. Thus, they confirm the construct validity (Gefen \& Straub, 2005). The reliability, convergent validity, discriminant validity, and unidimensionality are fulfilled, indicated by the results of unidimensionality adequate degree for each construct. 
Table 1

Result of the Measurement Model

\begin{tabular}{|c|c|c|c|c|c|}
\hline Construct & Items & Factor Loading $(t)(>0.7)$ & Cronbach's $\alpha(>0.7)$ & $\mathrm{CR}(>0.7)$ & $\begin{array}{l}\text { AVE } \\
(>0.5)\end{array}$ \\
\hline \multirow[t]{6}{*}{ Social Capital } & SC 1 & $0.815(10.553)$ & 0.881 & 0.910 & 0.627 \\
\hline & $\mathrm{SC} 2$ & $0.756(9.536)$ & & & \\
\hline & $\mathrm{SC} 3$ & $0.773(15.932)$ & & & \\
\hline & $\mathrm{SC} 4$ & $0.831(18.961)$ & & & \\
\hline & SC 5 & $0.770(7.679)$ & & & \\
\hline & SC 6 & $0.803(14.877)$ & & & \\
\hline \multirow[t]{4}{*}{ Knowledge Collecting } & $\mathrm{KC} 1$ & $0.862(24.422)$ & 0.807 & 0.874 & 0.635 \\
\hline & $\mathrm{KC} 2$ & $0.722(4.988)$ & & & \\
\hline & $\mathrm{KC} 3$ & $0.770(10.901)$ & & & \\
\hline & $\mathrm{KC} 4$ & $0.827(15.892)$ & & & \\
\hline \multirow[t]{3}{*}{ Knowledge Donating } & KD 1 & $0.852(22.013)$ & 0.757 & 0.858 & 0.670 \\
\hline & KD 2 & $0.862(23.910)$ & & & \\
\hline & KD 3 & $0.736(11.084)$ & & & \\
\hline \multirow[t]{4}{*}{ Innovation Capability } & IC 1 & $0.807(15.885)$ & 0.840 & 0.893 & 0.676 \\
\hline & IC 2 & $0.817(19.215)$ & & & \\
\hline & IC 3 & $0.879(29.925)$ & & & \\
\hline & IC 4 & $0.785(12.762)$ & & & \\
\hline
\end{tabular}

Table 2

Mean, Standard Deviation, and Correlations among Study Constructs

\begin{tabular}{lccccccc}
\hline \multicolumn{1}{c}{ Construct } & Mean & SD & AVE & $\mathbf{1}$ & $\mathbf{2}$ & $\mathbf{3}$ & $\mathbf{4}$ \\
\hline Innovation Capability & 0.672 & 0.055 & 0.676 & 0.822 & & & \\
Knowledge Collecting & 0.629 & 0.080 & 0.635 & 0.606 & 0.797 & & \\
Knowledge Donating & 0.666 & 0.049 & 0.670 & 0.702 & 0.702 & 0.819 & 0.792 \\
Social Capital & 0.617 & 0.078 & 0.627 & 0.626 & 0.697 & 0.646 & \\
\hline
\end{tabular}

Table 3

Item Loading and Cross-Loading

\begin{tabular}{ccccc}
\hline & IC & KC & KD & SC \\
\hline SC 1 & 0.461 & 0.529 & 0.504 & 0.815 \\
SC 6 & 0.455 & 0.536 & 0.451 & 0.756 \\
SC 2 & 0.481 & 0.506 & 0.489 & 0.773 \\
KC 1 & 0.563 & 0.862 & 0.618 & 0.612 \\
KC 2 & 0.395 & 0.722 & 0.483 & 0.527 \\
KC 3 & 0.464 & 0.770 & 0.531 & 0.537 \\
KC 4 & 0.495 & 0.827 & 0.597 & 0.544 \\
KD 1 & 0.644 & 0.616 & 0.852 & 0.590 \\
KD 2 & 0.613 & 0.641 & 0.862 & 0.632 \\
KD 3 & 0.432 & 0.433 & 0.736 & 0.299 \\
IC 1 & 0.807 & 0.563 & 0.593 & 0.592 \\
IC 2 & 0.817 & 0.475 & 0.587 & 0.531 \\
SC 3 & 0.577 & 0.513 & 0.555 & 0.831 \\
IC 3 & 0.879 & 0.501 & 0.580 & 0.495 \\
IC 4 & 0.785 & 0.444 & 0.544 & 0.425 \\
SC 4 & 0.409 & 0.601 & 0.483 & 0.770 \\
SC 5 & 0.570 & 0.620 & 0.574 & 0.803 \\
\hline
\end{tabular}

The second stage of data analysis is using partial least squares techniques. It performs through examining the variance measured $\left(R^{2}\right)$ by the antecedent constructs. The benchmark to interpret $R^{2}$ was taken from Cohen (1988) that is $0.02,0.13$ and 0.26 as the small, medium, and large variance, respectively. Af- terward, employing the bootstrapping technique and computing the $t$-values are done to obtain the significance of the path coefficients and total effects.

The current research found positive and significant relationship on social capital on knowledge collecting $\left(H_{l}, \beta 0.697, t\right.$-value $\left.6.839, p<0.001\right)$ and 
knowledge donating $\left(H_{2}, \beta 0.305, t\right.$-value 2.957, $p<0.001)$. Thus, it confirms that social capital influence knowledge collecting $\left(H_{l}\right)$ and knowledge donating $\left(\mathrm{H}_{2}\right)$ significantly. This outcome corresponds with Akhavan and Hosseini (2016). It is also revealed a significantly positive relationship for knowledge collecting on knowledge donating $\left(H_{3}, \beta 0.490, t\right.$ value $4.683, p<0.00)$. Moreover, this research finds significant positive correlation between knowledge donating and innovation capability $\left(H_{5}, \beta 0.466, t\right.$ value $4.034, p<0.001)$. This result corresponds with preceding studies (Lin, 2007; Zhi-Hong et al., 2008; Yesil et al., 2013; Kamasak \& Bulutlar, 2010).

On the contrary for $H_{4}$, the results indicate that knowledge collecting has no significant relationship on innovation capability $\left(H_{4}, \beta 0.102, t\right.$-value 0.693 , $p<0.001)$. Therefore, $H_{4}$ is rejected. The summary of hypothesis test results are presented in Figure 1 and Table 4.

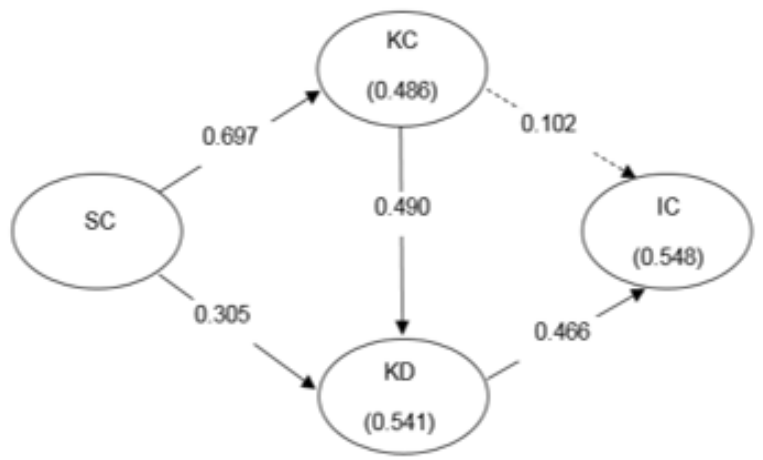

Figure 1

Result of SEM-PLS Model Abalysis

Table 4

Hypothesis Test Results

\begin{tabular}{|c|c|c|c|c|}
\hline $\begin{array}{l}\text { Hypo- } \\
\text { thesis }\end{array}$ & Path & $\begin{array}{c}\text { Path } \\
\text { Coefficient }\end{array}$ & $t$-Value & Results \\
\hline$H_{l}$ & $\mathrm{SC} \rightarrow \mathrm{KC}$ & 0.697 & 6.839 & Supported \\
\hline $\mathrm{H}_{2}$ & $\mathrm{SC} \rightarrow \mathrm{KD}$ & 0.305 & 2.957 & Supported \\
\hline$H_{3}$ & $\mathrm{KC} \rightarrow \mathrm{KD}$ & 0.490 & 4.683 & Supported \\
\hline$H_{4}$ & $\mathrm{KC} \rightarrow \mathrm{IC}$ & 0.102 & 0.693 & $\begin{array}{c}\text { Not } \\
\text { Supported }\end{array}$ \\
\hline$H_{5}$ & $\mathrm{KD} \rightarrow \mathrm{IC}$ & 0.466 & 4.034 & Supported \\
\hline
\end{tabular}

\section{Conclusions and Implications}

This research reveals that social capital has effected on both knowledge collecting and donating. Social capital becomes a valuable mechanism for universities to enable knowledge sharing. For that reason, it is suggested that universities should intensify the trust, networks, and norms among lectures to facilitate the knowledge sharing. Through such a solid relationship, knowledge sharing process could be acelerated.
The empirical result also demonstrates that knowledge donating has an impact on innovation capability, while knowledge collecting has not. The process of sharing knowledge could not stop at the stage of acquiring knowledge alone (van den Hoff \& de Ridder, 2004). A person must also be willing to deliver his knowledge, so that knowledge sharing can proceed perfectly. It is consistent with the norm of reciprocity in social capital (Putnam, 1995).Therefore, it is strongly recommended that both processes of knowledge sharing be completed before it can have a positive effect on the ability of innovation.

However, there are limitations of this research. The social capital construct of this research is only identified by trust, network and norms. Other perspectives of social capital could be considered for future studies. Moreover, the object of this research is lectures of private university in Surabaya. Since different local norms can affect social capital, it would be interesting to contrast the effect of social capital in several areas or regions.

\section{References}

Akhavan, P. \& Hosseini, S.M. (2016). Social capital, knowledge sharing, and innovation capability: An empirical study teams in Iran. Journal Technology Analysis \& Strategic Management, 28(1), 96-113.

Bullinger, H. J., Bannert. M., \& Brunswicker, S. (2007). Managing innovation capability in smes. Tech Monitor, Special Feature: Innovation \& KM by SMEs, 17-27.

Chin, W.W., Marcolin, B., \& Newsted, P. (2003). A partial least squares latent variable modeling approach for measuring interaction effects: Results from a Monte Carlo simulation study and an electronic-mail emotion/adoption study. Information Systems Research, 14(2), 189-217.

Chow, W.S. \& Chan, L.S. (2008). Social network, social trust and shared goals in organizational knowledge sharing, Information \& Management, 45(7), 458-465.

Cohen, J. (1988). Statistical power analysis for the behavioral sciences. Hillsdale, NJ: Lawrence Erlbaum.

Coleman, J. S. (1988). Social capital in the creation of human capital. American Journal of Sociology, 94, S95-S120.

-1990). Foundations of social theory. Cambridge: Harvard University Press.

Collin, C. J. \& Smith, K.G. (2006). Knowledge exchange and combination: the role of human resource practices in the performance of high technology firms. Academy of Management Journal, 49(3), 544-560. 
Dakhli, M. \& de Clercq, D. (2004). Human capital, social capital, and innovation: A multi-country study. Entrepreneurship and Regional Development, 16(2), 107-128.

Doh, S. \& Zolnik, E. J. (2011). Social capital and entrepreneurship: An exploratory analysis. African Journal of Business Management, 5(12), 4961-4975.

Faizuniah, P. \& Aizzat, M. N. (2009). Assessing the relationship between business commitment and knowledge sharing behavior. Malaysia and Management Journal, 13(1\&2), 35-50.

Fernie, S., Green, S. D., Weller, S. J., \& Newcombe, R. (2003). Knowledge sharing: Context, confusion and controversy. International Journal of Project Management, 21, 177-187.

Fornell, C. \& Larcker, D. F. (1981). Evaluating structural equation models with unobservable variables and measurement error. Journal of Marketing Research, 18(1), 39-50.

Fukuyama, F. (1995). Trust: Kebajikan sosial dan penciptaan kemakmuran. Jakarta: Qalam.

Gefen, D. \& Straub, D. (2005). A practical guide to factorial validity using PLS-graph: Tutorial and annotated example. Communications of the Association for Information Systems, 16(1), 91109.

Green, G. P. (1996). Social capital and entrepreneurship: bridging the family and community. Cornell University Conference on the Entrepreneurial Family - Building Bridges. March 17-19, 1996, New York.

Hair, J. F., Black, W. C., Babin, B. J., \& Anderson, R. E. (2010). Multivariate data analysis: A global perspective. NJ: Prentice Hall Upper Saddle River.

Hansen, M. T, Nohria, N., \& Tierney, T. (1999). What's your strategy for managing knowledge? Harvard Business Review, March-April 1999.

Ipe, M. (2003). Knowledge sharing in organizations: A conceptual framework. Human Resource Development Review, 2, 337-359.

Jackson, M. A., Hitt, \& DeNisi A. S. (Eds.). Managing knowledge for sustained competitive advantage: Designing strategies for effective human resource management, 155-177. San Francisco: Jossey Bass.

Kamasak, R. \& Bulutlar, F. (2010). The influence of knowledge sharing on innovation. European Business Review, 22(3), 306-317.

Knack, S. \& Keefer, P. (1997). Does social capital have an economic payoff? A cross-country investigation. The Quarterly Journal of Economic, 112(4), 1251-1288.
Koskinen, K. U., Pihlanto, P., \& Vanharanta, H. (2003). Tacit knowledge acquisition and sharing in a project work context. International Journal of Project Management, 21, 281-290.

Lin, H. F. (2007). Knowledge sharing and firm innovation capability: An empirical study. International Journal of Manpower, 28, 315-332.

Nahapiet, J. \& Ghoshal, S. (1998). Social capital, intellectual capital and the organizational advantage. Academy of Management Review, 23(2), 242-266.

Onyx, J. \& Bullen, P. (2000). Measuring social capital in five communities. The Journal of Applied Behavioral Science, 36, 23-43.

Plessis, M. D. (2007). The role of knowledge management. Journal Knowledge Management, 11(4), 20-29.

Pulakos, E. D., Dorsey, D. W., \& Borman, W. C. (2003). Hiring for knowledge-based competetion. In S. E. Jackson, M. A. Hitt, \& A. S. DeNisi (Eds.), Managing knowledge for sustained competitive advantage: Designing strategies for effective human resource management (155-177). San Francisco: Jossey Bass

Putnam, R. D. (1995). Bowling alone: America's declining social capital. Journal of Democracy, 6 , 65-78.

(2000). Bowling alone: The Collapse and revival of American community. New York, NY: Simon \& Schuster.

Rousseau, D., Sitkin, S., Burt R., \& Camerer, C. (1998). Not so different after all: A cross-discipline view of trust. Academic Management Review, 23, 393-404.

Roussel, C. S \& Deltour, F. (2012). Beyond crossfunctional teams: Knowledge integration during organizational projects and the role of social capital. Knowledge Management Research \& Practice, 10(2), 128-140.

Santarelli, E. \& Tran, H. T. (2012). The interplay of human and social capital in shaping entrepreneurial performance: The case of Vietnam. Small Business Economics: An Entrepreneurship Journal, 40(2), 435-458.

Sechi, G., Borri, D., Lucia, C. D., \& Celmins, V. (2011). Social capital as knowledge facilitator: Evidence from Latvia. Knowledge Management Research \& Practice, 9(3), 245-255.

Suresh, A. (2012). An empirical evaluation of critical success factor of KM for organization sustainability. Astiva International Journal of Commercial and Social Science, 1(1), 1-12.

Shah, S. R. \& Mahmood, K. (2013). Knowledgesharing behavior in dairy sector of Pakistan. Library Philosophy and Practice (ejournal), 917, 1-9. 
Terziovski, M. (2007). Building innovation capability in organizations: An international cross-case perspective. London: Imperaial College Press.

Tsai, F. S. (2005). Composite diversity, social capital, and group knowledge sharing: A case narration. Knowledge Management Research \& Practice, 3(4), 218-228.

Van den Hooff, B. \& de Ridder, J. A. (2004). Knowledge sharing in context: The influence of organizational commitment, communication climate and CMC use on knowledge sharing. Journal of Knowledge Management, 8(6), 117-130.

Van den Hooff, B. \& Huysman, M. (2009). Managing knowledge sharing: Emergent and engineering approaches. Information \& Management, 46(1), 1-8.

Wallin, J., Larsson, A., Isaksson, O., \& Larsson, T. (2011). Measuring innovation capability assessing collaborative performancein product-service system innovation. 3rd CIRP International Conference on Industrial Product Service System. Braunschweig.
Westlund, H. (2006). Social capital in the knowledge economy: Theory and empirics. NY: SpringerVerlag.

Witherspoon, L. C., Jason, B., Cam, C., \& Dan, S. N. (2013). Antecedents of business knowledge sharing: A meta-analysis and critique. Journal of Knowledge Management, 17(2), 250-277.

Yang, H. L. \& Wu, T. C. T. (2008). Knowledge sharing in an organization. Technological Forecasting \& Social Change, 75, 1128-1156.

Yesil, S., Kosta, A., \& Buyukbese, T. (2013). Knowledge sharing process, innovation capability and innovation performance: An Empirical study. Procedia-Social and Behavioral Sciences, 75, 217-225.

Zhi-Hong, S., Li-Bo, F., \& Shu, C. (2008). Knowledge sharing and innovation capability: Does absorptive capacity function as a mediator? International Conference on Management Science \& Engineering $\left(15^{\text {th }}\right)$, September 10-12, Long Beach, USA. 